\title{
Syntax for language teachers: Revisiting the nature of language
}

\author{
M. Tolkhah Adityas a,1,*, Ikmi Nur Oktavianti b,2, Icuk Prayogi c,3 \\ ${ }^{a}$ University of Auckland, Auckland CBD, Auckland 1010, New Zealand \\ ${ }^{\mathrm{b}}$ Universitas Ahmad Dahlan, Jl. Ringroad Selatan, Kragilan, Tamanan, Kec. Banguntapan, Bantul, Daerah Istimewa \\ Yogyakarta 55191, Indonesia \\ ${ }^{c}$ Universitas PGRI Semarang, Jl. Sidodadi Timur No.24, Karangtempel, Kec. Semarang Tim., Kota Semarang, Jawa \\ Tengah 50232, Indonesia \\ 1'madi031@aucklanduni.ac.nz*; ${ }^{2}$ ikmi.oktavianti@pbi.uad.ac.id; ${ }^{3}$ icukprayogi@gmail.com \\ *corresponding author
}

\section{ARTICLE INFO}

\section{Article history}

Received 11 December 2019

Revised 5 March 2020

Accepted 26 August 2020

Available Online 15 January 2021

\section{Keywords}

syntax

linguistics

language teachers

\section{ABSTRACT}

Teaching language is not only a matter of delivering language materials to the learners (e.g., using various methods or media), but it is also about what is thought and what is understood by the teachers that might contribute indirectly in designing and delivering the materials. Those aspects are the manifestations of teachers' knowledge about language. Teachers who have sufficient understanding on language will be able to conduct better practice of language teaching since they understand what they are teaching. It is then intriguing to discuss the roles of syntax for language teachers: what can teachers benefit from it? This paper aims at revisiting the importance of syntax for language teachers by looking at the nature of language and the nature of syntax. This paper reviews the available relevant literature. The result of discussion emphasizes the potentiality of syntax to equip teachers with adequate knowledge on language, language structure and how to cope with changes in language. Moreover, reading syntax research can enrich teachers' knowledge. This knowledge can be of beneficial for teachers, for instance in designing the language content of teaching materials. These are not surprising since language teachers are teaching language; therefore, they should also consider language characteristics of the language they are teaching.

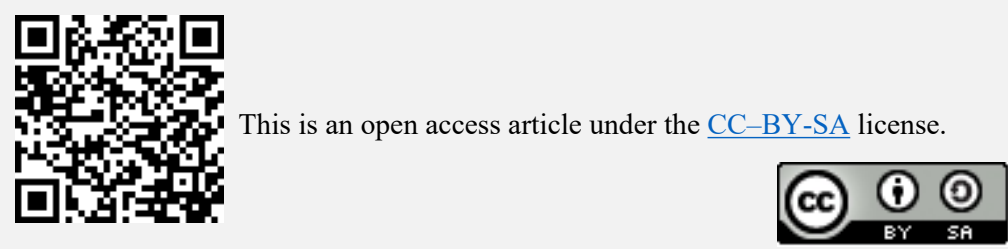

\section{Introduction}

In teaching a language, teachers should focus on enormous aspects to achieve the purpose of teaching. To assist teaching activity, teachers use methods, approaches, or strategies and they also design teaching materials or media. The roles of those aspects are obviously prominent in teaching, especially in the context of teaching foreign languages. With regard to this, language teaching practitioners study the use of approaches or strategies to improve learners' skills (e.g., Abad \& Alzate, 2016; Askia \& Manurung, 2016; Sharma, 2018; Zanjani \& Izadpanah, 2016); some others examine the use of particular media or teaching materials to enhance learners' skill (e.g., Fauza, Usman, \& Muslem, 2018; Gunada, 2017; Hardiah, 2019; Loren, 2017).

Apart from teaching methods, approaches, strategies, media, materials, and so forth, teachers themselves are the salient agent of the teaching practice. To this extent, language teachers enact several roles, including teachers as communicators (to communicate effectively with learners) and 
teachers as educators (to design teaching materials and activities) (Fillmore \& Snow, 2000). Both roles basically involve teachers' knowledge about language to enhance the quality of the communication and the quality of teaching materials. Linguistic knowledge is something that mostly we are unconscious of and comprise some aspects, such as the sounds, the structure of words, and the structure of sentences of a language (Gelderen, 2016). Teachers' linguistic knowledge, thus, is inevitably important and what is mastered or comprehended by teachers will be manifested through their selection of materials and activities and through the choice of words or linguistic construction used by teachers in the classrooms.

In regard to the significant role of teachers in language teaching, the discussion on teachers' knowledge is basically quite fundamental. Teachers' knowledge should incorporate practical knowledge (based on personal or shared experience) with more theoretical ones to support the teaching practice (Fillmore \& Snow, 2000). Theoretical knowledge of teachers includes, at least, pedagogical knowledge and linguistic knowledge, which they gain from previous formal education or continued professional training. Linguistic knowledge or knowledge about language is necessary and prominent for language teachers (Bigelow \& Ranney, 2010; Myhill et al., 2013; Prayogi, 2014; Whong, 2011; Wilson \& Scanlon, 2011). The knowledge about what language is and its characteristics might help teachers to select the materials or activities relevant to the needs of the learners from various linguistic backgrounds and linguistic competence (Sibomana, 2017; Whong, 2011; Wilson \& Scanlon, 2011). This has to do with the nature of language teaching itself as the transfer of language knowledge from teachers to learners. The transfer of language is plausible to happen since one of the characteristics of (human) language is the possibility to be transmitted to others (from the same generation or to the next generation) (Hockett cited in Rowland, 2014; Yule, 2010).

There have been some previous studies investigating teachers' knowledge and analyzing the roles of pedagogic knowledge (e.g., Estaji \& Dezfolian, 2018; Moradkhani, 2017; Muhamad \& Kiely, 2018; Mullock, 2006). Teachers' knowledge about language mainly talk about language knowledge in general (e.g., Jones \& Chen, 2012; Puliatte \& Ehri, 2018; Sibomana, 2017; Wilson \& Scanlon, 2011). More specifically, some also study the roles of grammatical knowledge comprehended by teachers have been studied in relation to its implication to teaching effectiveness or success (e.g., Bigelow \& Ranney, 2010; Myhill et al., 2013). Whereby in teaching language, one of the important elements is the teaching of the grammar (Zhang, 2009). The term grammar linguistically refers to descriptive rules of language (Crystal, 2010), and thus it covers morphology and syntax, with syntax studying the extra phrasal constructions or in the level of clause and sentence. In teaching English, teachers do not only list the vocabulary and tell the meanings, but it is about how to construct those words in a grammatical construction of English. Thus, syntax is definitely important to prepare teachers to teach language well, along with morphology.

Pedagogically, syntax is taught in language education departments (English, Indonesian, or others) to equip the prospective teachers with linguistic knowledge to be able to teach language well. In foreign language context, it is necessary to learn the language profoundly, including the syntactic characteristics. But based on the observation, most of the students (the prospective teachers) do not realize how important syntax is because they have no idea what syntax can offer to them as future language teachers. This paper, therefore, attempts to provide a preliminary review toward the existing literature related to syntax, the nature of language, and the benefits of studying and understanding syntax for language teachers.

\section{Research Method}

This paper employs literature review as the methodology because it aims at providing the overview of the roles of syntax for language teachers. According to Snyder (2019), literature review is the best methodology to answer particular research questions. Literature review as a methodology enables the researchers to provide theoretical answers to the subject matter. It means that this paper attempts to provide a theoretical basis for the observed phenomenon, that is, the benefits of studying syntax for language teachers.

Snyder (2019) points out that literature review as methodology is not surprising since the way to gather the information is similar to the data collection. Thus, in this paper, the data are relevant previous studies or relevant publication on syntax and the role of syntax (and linguistics) for 
language teaching. The analyses of the data include the process of identifying, understanding, meaning-making, and transmitting information (Onwuegbuzie, 2016).

\section{Findings and Discussion}

Syntax is defined as the study of sentence structure (Gelderen, 2016; Tallerman, 2015; Valin, 2004), albeit a more specific definition proposed by Adger (2019) pointing out that syntax is a cognitive capacity allowing humans to connect linguistic forms with meanings. The definition of syntax, however, remains debatable since it depends on the perspective of defining language. But they all share something in common: syntax is about forms.

Syntactic structure can be divided into grammatical relation, relational structure, and constituent structure (Valin, 2004). Grammatical relations deal with the syntactic function a particular linguistic unit occupies within a clause: be they subject, predicate, or object. Relational structure has to do with the relation between two linguistic units in phrasal constructions, as a head and as a modifier, namely modifier and modified or possesser and possessed. As for the constituent structure, it refers to the hierarchical binary structure of linguistic construction enabling the division of linguistic constructions into (two) smaller units.

However, syntax is definitely a broad topic, regarding the broad range of discussions it covers. To date, syntactic theories are numerous, emerging from various perspectives toward language and language structure, such as from mentalism perspective (e.g., Chomsky, 2002; Jackendoff, 1997), functionalism perspective (e.g., Halliday \& Matthiessen, 2004), or typology perspective (e.g., Dixon, 2005; Valin, 2004). As for language teachers, the knowledge of syntax should be delivered at least as the basis or fundamental knowledge of delivering language materials in teaching practice. More specifically, syntax is firmly related to (pedagogical) grammar, which results in the importance of understanding syntax and syntactic characteristics of a target language to the mastery and the teaching of the grammar of the target language.

Studying syntactic characteristics of the target language is of paramount for students of the language education department. This section thus emphasizes on the roles of comprehending syntax for language teachers in relation to the nature of language.

\subsection{Studying Syntax Informs the Teachers about the Nature of Language}

As language teachers, it is prominent to know what language is, instead of only knowing the methods or media to teach it to the learners (Prayogi, 2014; Whong, 2011). Most students will simply define language as a means of communication. This definition, however, lacks the nature of language, so it is important to redefine it according to what language is. It most likely yields a more rigorous definition, such as (1) language is an arbitrary symbol or (2) a system whose properties are limited to human cognitive capacity (Yule, 2010). These definitions are more about language than its function, so they are more philosophical and in accordance with the nature of language. These definitions will also enable the profound understanding of language not as a mere object, but it is also a system whose elements or properties work together. Thus, if there is a change in a specific element, it would affect the other (Poedjosoedarmo, 2000).

Suffice to say, syntax encompasses basic understanding of language. By studying syntax, language teachers will be equipped with other basic knowledge, such as the basic properties of human language, allowing for the creativity of the users in generating language. Language is built by a limited set of rules to generate unlimited linguistic constructions (Chomsky, 2002). Specifically, in constructing language structure, people are allowed to recursively combine patterns, such as in Dorothy thinks that Toto suspects that Tin Man said that.... (Carnie, 2012; Chomsky, 2009). Below are the examples of how recursive patterns work in language (i.e., English).

(1) a. The gun was on the table.

$b$. The gun was on the table near the window.

c. The gun was on the table near the window in the bedroom.

For this claim, thus, there is no such thing as 'the longest sentence in the world' since people could easily add another repeated pattern to make any other sentences longer. 
As a system, language is part of human cognitive ability, and thus it is innate (Haegeman, 1998). It is believed that human language has some fundamental principles that can be applied to all (or nearly all) languages in the world. This refers to Universal Grammar relying on the fact that children acquiring language with the same linguistic pattern across languages. Theoretically there must be some inherent properties wired in the brain of children in relation language acquisition and language production. Observing language production of children is the simplest way to look at universality of language. The absolute universal principle among languages, for example, is that all languages have nouns (Comrie, 1989), proven with the production of nouns as the first words of children in different languages (O'Grady, 2005).

Universality also comes in the form of the structure. All languages have their structures or patterns, though the more specific patterns are more language-specific. English, for instance, is a SVO language, while Japanese is a SOV language. This knowledge is beneficial for language teachers since they will be able to explain more about the nature of language. In terms of the nature of language structure, according to Culicover \& Jackendoff (2005), human languages show uniformity in terms of their simplicity. Language works economically and in a simple fashion as is seen in the phenomena of phonetic reduction (e.g., wanna, gonna) and contractions of chunks (e.g., I'll, she's). Thus, in many theories of language change, language is heading toward efficiency and applying economy principle fundamentally (Gelderen, 2016). Teachers need to be theoretically well informed about the nature of language from studying and understanding syntax to enhance the language teaching quality. The task of language teaching requires the teachers to think of the nature of language since it will determine the way the teachers select particular methods of teachings or provide insights for the teaching practice (van der Walt, 2012).

\subsection{Understanding Syntax Means Understanding that Language Structure is Basically Binary and Hierarchical}

One of the basic needs when talking about language is talking about its structure. Language teachers should familiarize themselves with the structural characteristics of the target language being taught. In syntax, we can identify that language structure is universally binary which means that only two linguistic units can be merged together to form larger linguistic construction (e.g., from words to phrases or from phrases to clauses) (Adger, 2019). This principle corresponds to computational procedure that only allows binary combination during the processing of things. In constructing structure, the basic operation needed is merge, that is combining two smaller units into one bigger unit, and it is relevant with binary structure of language.

This nature, however, does not seem to explain anything about particular constructions, such as in Indonesian history teacher. In regard to this, teachers should be able to understand two possible interpretations whether it is [Indonesian [history teacher]] or [Indonesian history [teacher]]. We can illustrate them in two different tree diagrams as in below.

(2) First interpretation: [Indonesian [history teacher]]

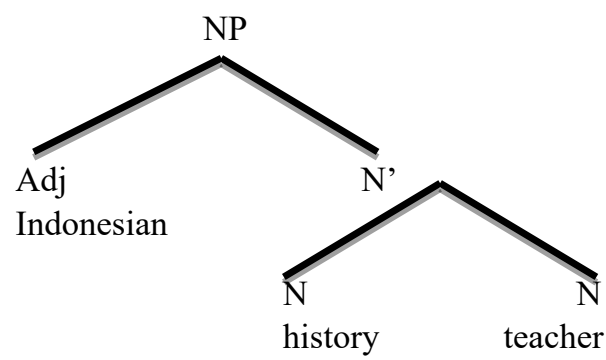


(3) Second interpretation: [[Indonesian history] teacher]

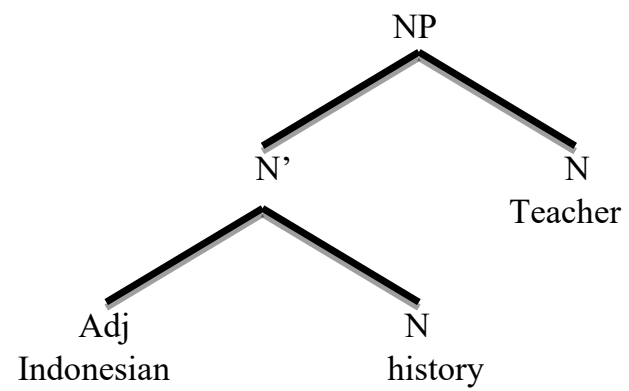

To this extent, we can notice that in the first interpretation, the NP has basically one smaller NP history teacher and a noun (as modifier) Indonesian. Meanwhile, in the second interpretation, there is one smaller NP Indonesian history as a modifier and a head noun teacher. This refers to the structural ambiguity of language (Saeed, 2015; Valin, 2004). Based on the tree diagram, it is noticeable that the structure is hierarchical and different hierarchy marks different interpretations. It encompasses language structure as, not only binary, but also hierarchical. Understanding syntax allows teachers to consider this aspect and be more helpful for the students or learners in profoundly studying language. Teachers who understand syntax well might be able to explain more comprehensively about language structure.

\subsection{Studying Syntax Strengthens Grammatical Knowledge}

As part of (linguistics) grammar, studying syntax might also contribute to the understanding of teachers toward grammatical rules. In linguistics, grammar is not limited to the prescriptive rules on how people should speak or write. It is actually the description of how people actually use the language. Morphology and syntax, in linguistics, are parts of grammar. What makes this even more interesting is that grammar should have (not only descriptive power, but also) explanatory power (Carnie, 2012). Therefore, grammar is not a mere shibboleth of rules, but there is also a reason behind the rules, diachronically or synchronically. Syntax provides underlying reasons of the rules in grammar so by having sufficient syntactic knowledge (and awareness), teachers are able to explain it to students or take it into consideration in teaching practice. Besides, to teach grammatical accuracy, the teachers need some knowledge of morphology and syntax (Cunningham, 2015).

One of the major discussions in English grammar is the discussion on tenses. Aside from the fact that it is the major characteristic of Indo-European languages (including English), many other languages do not have tenses for their temporal markers. Relating it to Indonesian, it is not surprising to see many students or learners struggle a lot when it comes to learn and use tenses. As language teachers, it is then part of our tasks to describe types of English tenses to the students (e.g., nature, patterns, use, etc.). Nevertheless, it is also salient for the teachers to know what actually tenses are and are able to answer philosophical questions, such as 'why English has tenses while Indonesian doesn't have any' (Oktavianti, 2014). More importantly, tenses are the heads in English clauses because without tenses, English clauses are ungrammatical. In Minimalist Program, thus, there is IP (Inflectional Phrase) whose members are tenses inflection as the head of a clause (the term IP revolutionary replaces the term $\mathrm{S}$ for the top node of tree diagram) (Radford, 1997).

Besides, having adequate syntactic understanding will inform the teachers that basically there are only two types of tenses in English; they are past tense and non-past tense (i.e., present tense and future tense). That is why in present tense, it is not only about now, but also about tomorrow or timeless events, while in future tense there are marked constructions using paraphrastic will + verb or be going to + verb to mark the tense. Furthermore, teachers who learn and understand syntax are be able to figure that pedagogical tenses (those designed for pedagogical purpose), such as present progressive tense, present perfect tense actually consist of two elements: tense and aspect (Comrie, 
1976; Oktavianti \& Prayogi, 2018). Therefore, present progressive tense means it consists of present tense and progressive aspects. This knowledge enables teachers to be more accurate in using the language and in teaching the language. It will also enable teachers to comprehend the relation between grammatical elements (Wilkins, 1975), e.g., tenses and aspects, and how they interact in linguistic structure. Simply as an understanding for the teacher this is very useful. They will be able to learn new grammatical materials and know the reasons behind it, design grammar materials accordingly, and are prepared to answer critical questions from the students.

\subsection{Understanding Syntax Equips Teachers to be more Open-minded}

Syntax exhibits the descriptive rules of language, i.e., how language is actually used by the speakers (Crystal, 2010; Murray \& Christison, 2011). Language teachers who study and understand syntax can figure out that there are distinctive characteristics of each language in the world. Rather than focusing on the fluency of the target language for foreign language learners, it is important to consider the influence of the L1 during the learning process. It is plausible to make mistakes when studying a language because of the influence of the L1 (e.g., Indonesian or Javanese) with different characteristics from the target language (e.g., English).

In a particular language, syntax describes the actual patterns of the language. The patterns like $I$ didn't take none or He don't like the song are ungrammatical prescriptively, but descriptively it might be the results of dialectal influence (as in American African Vernacular English). When most teachers think of the word grammar, they often think of the prescriptive rules. To be able to understand that there are some variants of structure of a language, e.g., in English, is prominent for language teachers (Murray \& Christison, 2011), so they will have a positive attitude towards language use and result in a positive attitude toward language learning.

Not only in terms of the L1, In addition, language is dynamic as it is used (spoken or written) by dynamic society. Over time, language changes as it follows the changes of the society, including the change of the structure. Experimentally, it is proven that the larger the society of the language, the simpler the language. On the contrary, the smaller the society, the more complex the language (e.g. Reali et al., 2018). As English is getting widely used, across the globe, the structure of the language is getting simpler morphosyntactically and syntactically (compared to the older periods of English, e.g., Middle English or Early Modern English). Pedagogically, teachers should prescribe what they should speak or write (by teaching prescriptive grammar/pedagogical grammar), but fundamentally (especially in foreign language context), teachers should be very descriptive when seeing language and language use.

\subsection{Reading Syntax Research Enriches Teachers' Linguistic Knowledge}

There are so many studies focusing on syntax of a particular language or the comparison of syntactic characteristics between two languages. Teachers who most likely set aside the time to read some syntax books or syntax research are in the possibility of developing quality language input. This is due to the enrichment of teachers' linguistic knowledge. In foreign language teaching context, this should be highlighted since more knowledge on syntax will assist the teachers to actually deal with language and language teaching. So, the teaching practice will be more valuable because the content (i.e., the language being taught) is research-informed, not only based on the (most probably) inaccurate intuition of the teachers. There are oodles number of syntax research contrasting two different languages, such as studying the realization of modality, temporality, and aspectuality in English and Indonesian (Oktavianti \& Prayogi, 2018), analyzing the nominalization in English, Indonesian, and Javanese (Oktavianti et al., 2019), or comparing modals in English and the counterparts in Indonesian Other researchers are analyzing the different structure of English and Indonesian (e.g., Oktavianti, 2019).

As language teachers, it is insufficient to only rely on intuition or subconscious language awareness (tacit knowledge of language). According to Murray \& Christison (2011), teaching a language requires conscious knowledge of language. Reading these types of research findings are necessary since teachers should develop conscious knowledge of language (Murray \& Christison, 2011), and these syntax studies would likely to enrich the knowledge of language teachers in the classroom, especially for higher levels of education (Wilkins, 1975). The results of these sorts of research will enrich and deepen teachers' understanding of language and they will be more considerable of the language input they use in teaching the language. It is necessary to become skillful teachers, but it will be more complete if the teachers are also knowledgable, especially 
about language. Language teachers need to have analyzed the structure of the target language and the learners' first language, they will be empowered and are prepared to carry out researchinformed language teaching (Cunningham, 2015).

To sum up the discussion and bring it into a more practical area, there are three at least three pedagogical aspects that can be benefited from the understanding of syntax. The first one is the material selection. It is little doubt that linguistics generally provides important application to language teaching in terms of the preparation of the syllabuses and materials (Timmis, 2015). By understanding the syntax of the target language, teachers will be able to consider some aspects in the selection of materials: which should be prioritized, which should be taught earlier, and which should be repeated (Wilkins, 1975; van der Walt, 2012; Whong, 2011; Prayogi, 2014). When we write language teaching materials, we base the content on what we know of the language we are teaching. The way to obtain the knowledge is enormous, including from the grammatical description of the language (Wilkins, 1975). Our decisions (regarding the materials selection) should be taken in full awareness of the linguistic significance of what we are doing (Wilkins, 1975).

Aside from the materials, practically, teachers trained in linguistics (including syntax) would be able to identify the most frequent errors in EFL teaching, such as errors in subject-verb agreements, aspect, and tenses (De Klerk, 2014). This means that these teachers are ready to cope with students' errors and are theoretically informed on how to deal with the errors (due to the interference of L1, and others).

In relation to the teachers' competence, linguistics plays a significant role. Having sufficient understanding on syntax equips the teachers to provide good explanations of grammatical rules. Thus, teachers can provide the learners or students with grammatical explanation (De Klerk, 2014). It is evident that, despite the shift of the relationship between linguistics and language teaching from a direct relationship to a more indirect one (Van der Walt, 2012), linguistics cannot be overlooked in language teaching.

\section{Conclusion}

To be knowledgeable language teachers, profound understanding on what is being taught is of paramount importance. Therefore, the comprehension of syntax and syntactic characteristics of the language being taught is inevitably beneficial, in terms of the quality of the teaching materials and teaching activity. Teachers should realize that teaching a language is not only about the methodology or the media, but it is also about the language itself. Understanding that studying syntax is a salient part of being a competent language teacher should be emphasized, especially in language education departments.

\section{References}

Abad, J.V. \& Alzate, P.A. (2016). Strategies instruction to improve the preparation for English oral exams. PROFILE Issues in Teachers' Professional Development, 18(1), 129-147. Doi: https://doi.org/10.15446/profile.v18n1.49592

Adger, D. (2019). Language unlimited. Oxford: Oxford University Press.

Askia, S. \& Manurung, K. (2016). Improving speaking skills through active learning strategy of the year eight students. E-Journal of English Language Teaching Society, 4(2), 1-13.

Bigelow, M. \& Ranney, S. (2010). Knowledge about language for teachers is more than knowing grammar rules. Studies in Hispanic and Lusophone Linguistics, 3(1), 217-228. Doi: https://doi.org/10.1515/shll2010-1070

Carnie, A. (2012). Syntax: A generative introduction (3rd e.). New Jersey: Wiley-Blackwell.

Chomsky, N. (2002). Syntactic structures. New York: Mouton de Gruyter.

Chomsky, N. (2009). Cartesian linguistics (3rd ed.). Cambridge: Cambridge University Press. Doi:10.1017/CBO9780511803116 
Comrie, B. (1976). Aspect: An introduction to the study of verbal aspect and related problems. Cambridge: Cambridge University Press.

Comrie, B. (1989). Language universals and linguistic typology. Chicago: The University of Chicago Press.

Crystal, D. (2010). The Cambridge encyclopedia of language. Cambridge: Cambridge University Press.

Culicover, P.W., \& Jackendoff, R. (2005). Simpler syntax. Oxford: Oxford University Press.

Cunningham, U. (2015). Language teachers' need for linguistics. Linguistic Society of New Zealand, 58, $77-$ 94.

De Klerk, V. (2014). Why language teachers need linguistics. Stellenbosch Papers in Linguistics Plus, 21, 77-94. Doi: https://doi.org/10.5842/21-0-532

Dixon, R.M.W. (2005). A semantic approach to English grammar. New York: Oxford University Press.

Estaji, M. \& Dezfolian, S. (2018). EFL teacher's pedagogical knowledge base as a predictor of teacher's reflectivity: Comparing different components and perceptions. International Journal of Instruction, 11(3), 491-510. Doi: https://doi.org/10.12973/iji.2018.11334a

Fauza, H., Usman, B., \& Muslem, A. (2018). Improving students' speaking skill and motivation by using hand puppets show media. English Education Journal, 9(2), 216-218.

Fillmore, L.W. \& Snow, C.E. (2000). What teachers need to know about language. In C. T. Adger, C. E. Snow, \& D. Christian (Eds.). What teachers need to know about language (pp. 8-51). Bristol, UK: Multilingual Matters.

Gelderen, E. van (Ed.). (2016). Cyclical change continued. Amsterdam: John Benjamins Publishing Company.

Gunada, I.W.S. (2017). Using YouTube video; An IT-based media to improve students' speaking skill (Unpublished manuscript). Department of English Language Education, Ganesha University of Education.

Haegeman, L. (1998). Introduction to government and binding theory. Oklahoma: Blackwell.

Halliday, M.A.K., \& Matthiessen, C.M.I.M. (2004). An introduction to functional grammar (3rd ed.). USA: Oxford University Press.

Hardiah, M. (2019). Improving students listening skill by using audio visual media. Al-Lughah: Jurnal Bahasa, 7(2), 39-49. Doi: https://doi.org/10.29300/lughah.v7i2.1673

Jackendoff, R. (1997). The architecture of the language faculty. Cambridge, MA: MIT Press.

Jones, P.T., \& Chen, H. (2012). Teachers' knowledge about language: Issues of Pedagogy and Expertise. Research Online, 35(1), 147-168.

Loren, F.T.A. (2017). The use of learning media on listening skill in teaching Indonesian to speakers of other language (TISOL). Lingua Didaktika: Jurnal Bahasa Dan Pembelajaran Bahasa, 11(1), 1-12. https://doi.org/10.24036/ld.v11i1.7625

Moradkhani, S. (2017). Language teacher educators' pedagogical knowledge: Validating a proposed model. Iranian Journal of Language Teaching Research, 5(2), 91-111.

Muhamad, M. \& Kiely, R. (2018). Understanding teachers' pedagogical knowledge in ESL vocabulary teaching. Journal of Arts and Humanities, 7(1), 36-47. Doi: https://doi.org/10.18533/journal.v7i1.1328

Mullock, B. (2006). The pedagogical knowledge base of four TESOL teachers. The Modern Language Journal, 90(1), 48-66. Doi: https://doi.org/10.1111/j.1540-4781.2006.00384.x

Murray, D.E., \& Christison, M. (2011). What English language teachers need to know. New York: Routledge.

Myhill, D., Jones, S., \& Watson, A. (2013). Grammar matters: How teachers' grammatical knowledge impacts on the teaching of writing. Teaching and Teacher Education, 36, 77-91. Doi: https://doi.org/10.1016/j.tate.2013.07.005

O'Grady, W. (2005). How children learn language. Cambridge: Cambridge University Press. 
Oktavianti, I. N. (2019). A corpus-based analysis of English core modal verbs and their counterparts in Indonesian. International Journal of Scientific and Technology Research, 8(12), 2811-2819.

Oktavianti, I. N., Chaerani, N., \& Prayogi, I. (2019). Analisis kontrastif nominalisasi dalam bahasa Inggris, bahasa Indonesia, dan bahasa Jawa. SASDAYA: Gadjah Mada Journal of Humanities, 3(2), 103-119. Doi: https://doi.org/10.22146/sasdayajournal.50343

Oktavianti, I.N. (2014). Kuasi-Kopula dalam Bahasa Inggris. Yogyakarta: Gadjah Mada University Press.

Oktavianti, I.N., \& Prayogi, I. (2018). Realisasi temporalitas, aspektualitas, dan modalitas dalam bahasa Inggris dan bahasa Indonesia. Adabiyyāt: Jurnal Bahasa dan Sastra, 2(2), 181-201. https://doi.org/10.14421/ajbs.2018.02202

Onwuegbuzie, A.J., \& Frels, R. (2016). Seven steps to a comprehensive literature review. CA: SAGE.

Poedjosoedarmo, S. (2000). Syntactic change in Malay. Phenomena: Journal of Language and Literature, $4(2)$.

Prayogi, I. (2014). Peranan linguistik dalam pengajaran bahasa (sebuah catatan ringan). Sasindo, 2(2). Doi: https://doi.org/10.26877/sasindo.v2i2\%20Agustus.976

Puliatte, A., \& Ehri, L. C. (2018). Do 2nd and 3rd grade teachers' linguistic knowledge and instructional practices predict spelling gains in weaker spellers? reading and writing, 31(2), 239-266. Doi: https://doi.org/10.1007/s11145-017-9783-8

Radford, A. (1997). Syntax: A minimalist introduction. Cambridge: Cambridge University Press.

Reali, F., Chater, N., \& Christiansen, M.H. (2018). Simpler grammar, larger vocabulary: How population size affects language. Proceedings of the Royal Society B: Biological Sciences, 285(1871), 20172586. Doi: https://doi.org/10.1098/rspb.2017.2586

Rowland, C. (2014). Understanding child language acquisition. New York: Routledge.

Saeed, J. (2015). Semantics. New Jersey: WIley-Blackwell.

Sharma, D.R. (2018). Action research on improving students' speaking proficiency in using cooperative storytelling strategy. Journal of NELTA Surkhet, 5, 97-105. Doi: https://doi.org/10.3126/jns.v5i0.19495

Sibomana, E. (2017). A reflection on linguistic knowledge for teachers of English in multilingual contexts. Southern African Linguistics and Applied Language Studies, 35(1), 93-104. Doi: https://doi.org/10.2989/16073614.2017.1302351

Snyder, H. (2019). Literature review as a research methodology: An overview and guidelines. Journal of Business Research, 104, 333-339. Doi: https://doi.org/10.1016/j.jbusres.2019.07.039

Tallerman, M. 2015. Understanding Syntax (4th ed.). New York: Rouletge.

Timmis, I. (2015). Corpus linguistics for ELT: Research and practice. New York: Routledge, Taylor \& Francis Group.

Valin, R.D.V. (2004). An introduction to syntax. Cambridge: Cambridge University Press.

Van der Walt, J.L. (2012). Linguistics and second language teaching: An assessment. Stellenbosch Papers in Linguistics, 25(0), 169-182. Doi: https://doi.org/10.5774/25-0-80

Whong, M. (2011). Language teaching: Linguistic theory in practice. Edinburgh: Edinburgh Univ Press.

Wilkins, D.A. (1975). Linguistics in language teaching. London: Edward Arnold.

Wilson, A. \& Scanlon, J. (2011). Language knowledge for primary teachers (4th ed.). New York: Routledge.

Yule, G. (2010). The study of language (4th $\mathrm{ed}$.). Cambridge: Cambridge University Press.

Zanjani, B.A. \& Izadpanah, S. (2016). The impact of listening strategies on improving learners' listening skill in Iran. Journal of Language Teaching and Research, 7(6), 1089-1096. Doi: https://doi.org/10.17507/jltr.0706.04

Zhang, J. (2009). Necessity of grammar teaching. International Education Studies, 2(2), 184-187. Doi: https://doi.org/10.5539/ies.v2n2p184 
